\title{
次号予告
}

熱安定処理した高配同ポリエチレンテレフダレート䋐維の配向挙勘 .岡島三郎・㾟山和夫 高配向ポリビニルアルコール皮膜の延伸収縮による非晶領域の配向度の变化 岡島三郎・宇田川好隆

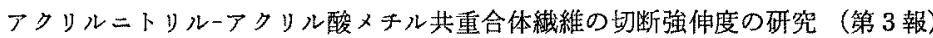
..高久 明・岸遖行 高分子村料のふく射保数の測定について（第 1 報)，(第 2 報) .宮阪芳喜・藤倉嘉昭 製織過程に甜けるタテ糸の粘弾性效果について（第 1 報）………沢木汀二・堀江勤之助・浅野洋輔・安䦭，順 ヒルロースの光崩壊に関寸る研究（第 7 報） 鯨 井，忠 五 羊毛緎維に対するアタリルニトリル $(\mathrm{AN})$ のダラフト共重合 長野正满・黑田栄美 液体亜硫酸中下呿子る高分子物質の学動（第 1 報） 泰 邦男・横田金吾

\section{3 月号予告}

アクリルニトリルーアクリル酸メヂル共重合体㵶維の切断強伸度の研究（第 4 報）……䯩久 明・岸 直行 羊毛フェルトに関する研究（第 1 報）…….......................清水昭二・池上 登・酒井啓吉・坂口康羡 同上（第 2 報） 清水昭二・池上 登・坂口康義

同上(第-3 報) 同] 上

光增感によるチロシンートリプトファン水溶液の黄褐变について 中村 勉. 竹村寿二 紡毛スライパのローラドラフトについて（第 4 報） 墨崎新也・近田淳雄 同上（第 5 報） 同上

防水加工による各種繊維集合体の耐水王効果について 佐貫治夫・戸辺武・安藤克彦

(訳 正)

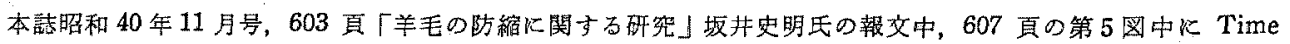
of Treatmentと説明がありますが, Felting Timeの誤りにつき訂正いたします。

昭和 41 年 1 月 5 日印剧 昭和 41 年 1 月 10 日発行 定洒 200 円 送料 12 円

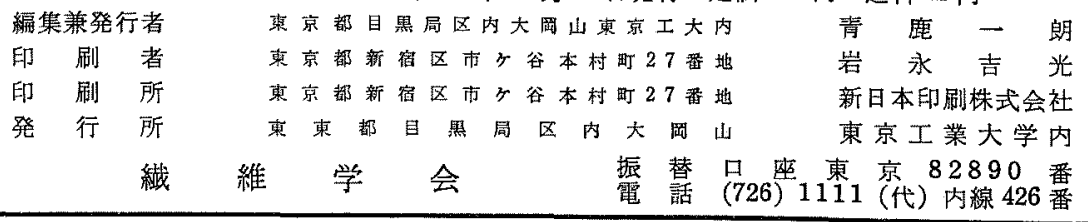

